\title{
GAYA HIDUP REMAJA PENGGUNA SMARTPHONE DI KOTA MALANG
}

\author{
Muhammad tony irwanto \\ Prodi Manajemen FEB UMM \\ E-mail: toni.irawan222@gmail.com
}

\begin{abstract}
The purpose of this study had identify and analyze the youth lifestyle Smartphone users in Malang. The usefulness of this research can be used as the basis for the company's consideration in developing Smartphone products produced and tailored to the consumer'lifestyle. Population in this study is that consumers Smartphone users in Malang, with characteristics that respondents who have entered in the category of age and adolescents, using judgmental sampling techniques can then be determined as many as 100 sample. Data analysis techniques used in this research is the analysis of the cluster. From the results of research and discussion, it can be concluded that the cluster I have a characteristic that is the willingness of respondents to support the work ruitn performed, work or routine activities are carried out, the development of information media, the activities undertaken by a person as a source of income, neighborhood closest to a person, always had a desire to buy the latest products, more priority to the purchase of goods after the wants rather than needs, support penampilandan add relationships / peer. Cluster III has the characteristic that the respondent wishes to keep up with technology, where it makes the respondent is always working to get information lengkao by utilizing technological developments.
\end{abstract}

Keywords: Teen ,Lifestyle, Smartphone

\section{PENDAHULUAN}

Faktor pribadi merupakan faktor internal konsumen yang memberikan dukungan terhadap keputusan yang akan dilakukan. Salah satu faktor tersebut adalah mengenai gaya hidup, faktor tersebut memberikan dukungan dalam upaya untuk memberikan dukungan untuk melakukan pembelian. Selain itu gaya hidup juga akan mempengaruhi sesorang untuk menentukan pilihanpilihan konsumsinya. Gaya hidup ditunjukkan oleh perilaku seseorang yang menganut nilai-nilai dan tata hidup yang hampir sama. Gaya hidup secara luas diartikan bagaimana orang menghabiskan waktu mereka (aktivitas), apa yang mereka anggap penting dalam lingkungannya (ketertarikan), dan apa yang mereka pikirkan tentang diri mereka sendiri dan juga dunia di sekitarnya. Gaya hidup yang berkembang di masyarakat dapat memberikan gambaran mengenai nilai-nilai yang dianut oleh masyarakat itu sendiri. Gaya hidup seseorang akan berbeda dengan seseorang yang lainnya. Bahkan dari masa ke masa gaya hidup suatu individu tertentu akan bergerak dinamis dan berbeda antara masyarakat satu dengan yang lainnya.Kondisi ini menjadikan perusahaan harus benar-benar mengikuti perubahan gaya hidup 
yang terjadi sehingga mampu bertahan dari kondisi persaingan yang semakin ketat. Analisis terhadap gaya hidup konsumen dapat memberikan suatu gambaran mengenai sejauh mana produk atau jasa yang ditawarkan dapat diterima oleh konsumen. Kemampuan perusahaan untuk memahami gaya hidup konsumen akan memberikan dukungan dalam upaya menentukan produk yang akan ditawarkan kepada konsumen dan sesuai dengan harapan konsumen. Gaya hidup konsumen juga berdampak pada perubahan atau perkembangan industri telekomunikasi.

Perkembangan industri telekomunikasi Indonesia saat ini menjadi segmen industri yang tumbuh besar dan berkembang pesat.Sektor telekomunikasi telah ikut andil dalam memberikan kontribusi pada pendapatan ekonomi negara. Sarana komunikasi yang semula hanya berupa telepon rumah (fix line) telah bergeser menjadi telepon seluler (mobile phone) atau biasa disebut telepon genggam (handphone). Sesuai dengan namanya handphone adalah alat komunikasi yang bentuknya tidak lebih besar dari telapak tangan dan dapat dibawa kemana saja, dan kini telah menjadi suatu kebutuhan primer bagi masyarakat.Fungsinya sebagai alat komunikasi jarak jauh, benar-benar dimanfaatkan oleh masyarakat sebagai sarana untuk melakukan berbagai macam transaksi tanpa dipengaruhi oleh waktu dan tempat.

Berdasarkan data yang di rilis oleh W\&S GROUP INDONESIA, dengan melalukan survey online terhadap 1.115 responden di kota malang, dapat dilihat pada tabel 1 .
Tabel 1. Data Penjualan 7 Merek

Smartphone Penjualan Terbaik

Tahun 2015

\begin{tabular}{ll}
\hline Merek & $\begin{array}{l}\text { Prosentase } \\
\text { Penjualan }\end{array}$ \\
\hline Samsung & $26,2 \%$ \\
Asus & $18,4 \%$ \\
Oppo & $16,9 \%$ \\
Lenovo & $15,7 \%$ \\
Sony & $12,8 \%$ \\
Iphone & $5,5 \%$ \\
Blackberry & $4,5 \%$ \\
\hline
\end{tabular}

Sumber: id.techinasia.com

Tabel 1 menunjukkan prosentase penjualan hasilnya samsung merupakan merek terpopular dan paling banyak penggunanya selain harga yang terbilang terjangkau namun memimiliki kwalitas yang bagus, selanjutnya disusul oleh asus karena asus memiliki harga yang relatif lebih murah dan kwalitasnya lumayan bagus dan disusul oleh beberapa merek smartphone ternama lainnya, dalam penelitian ini W\&S menemukan bahwa pengguna smartphone di kota malang merupakan tipe pengguna yang konsumtif dan gemar berganti-ganti smartphone sebanyak 59,9\%. demikian kondisi ini menjadikan persaingan pasar smartphone semakin ketat. Kondisi ini terjadi karena jika awalnya pengguna smartphone ini adalah para pejabat atau karyawan swata, wanita karir juga eksekutif muda, terutama khususnya kaum dewasa, lalu beralih ke remaja hingga anak-anak bahkan anak usia dini. Biasanya kaum dewasa menggunakan smartphone bertujuan untuk menambah relasi bisnis, menjalin kontak dengan relasi, keluarga, tutor, murid, pasangan dan sebagainya.

Kelompok remaja dengan menggunakan smartphone lebih bertujuan menambah teman baru atau 
bergabung dengan kumpulan group yang ada di sosial media. Kenyatan ini menjadikan keberadaan smartphone bukan lagi menjadi produk yang mahal atau mewah melainkan menjadi suatu kebutuhan bagi masyarakat dan lebih jauh lagi keberadaan smartphone telah menjadi bagian dari gaya hidup seseorang. Gaya hidup dalam penggunaan smartphone menjadikan keberadaan produk tersebut menjadi hal penting atau utama.

\section{TINJAUAN PUSTAKA}

Mayasari (2012), melakukan analisis perilaku konsumen pembelian ponsel cerdas antara kebutuhan dan gaya hidup konsumen di Kota Padang. Alat analisis data yang digunakan yaitu menggunakan metode analisis regresi linier berganda. Hasil analisis dapat diketahui bahwakebutuhan dan gaya berpengaruh terhadap keputusan konsumen dalam melakukan pembelian ponsel cerdas di Kota Padang. Hasil penelitian terdahulu yang digunakan yaitu penelitian Purba (2013) tentang pengaruh gaya hidup terhadap proses keputusan pembelian smarthphone berbasis android. Alat analisis yang digunakan yaitu menggunakan metode analisis regresi linier berganda. Hasil analisisdiketahui bahwa gaya hidup berpengaruh terhadap keputusan konsumen dalam melakukan pembelian smartphone berbasis android.

Perilaku konsumen menunjukkan aktivitas yang dilakukan konsumen dalam menentukan keputusan yang akan ditetapkan, perilaku konsumen juga menunjukkan aktivitas yang dilakukan seseorang untuk mendapatkan produk atau jasa yang dibutuhkan. Swasta dan Handoko (2000) menyatakan bahwa: Perilaku konsumen (consumer behavior) dapat didefinisikan sebagai kegiatan-kegiatan individu dan secara langsung terlibat dalam mendapatkan dan mempergunakan barang-barang dan jasa, termasuk didalamnya proses pengambilan keputusan pada persiapan dan penentu kegiatan-kegiatan tersebut. Menurut American Marketing Assotiation yang dikutip Peter dan Olson (2002) mendefinisikan perilaku konsumen sebagai interaksi dinamis diantara pengamat-pengamat kognisi, perilaku dan kejadian disekitar kita dimana manusia melakukan obyek pertukaran dalam hidup mereka.

John,

$\mathrm{dkk}$ mendefinisikan perilaku konsumen sebagai studi tentang unit pembelian (buying unit's) dan proses pertukaran yang melibatkan perolehan, konsumsi dan pembuangan barang, jasa serta pengalaman serta ide-ide. Lamb, dkk (2001) menyatakan bahwa perilaku konsumen merupakan proses seorang pelanggan dalam membuat keputusan membeli, juga untuk menggunakan dan membuang barang-barang dan jasa yang dibeli, juga termasuk faktor-faktor yang mempengaruhi keputusan pembelian dan penggunaan produk.

Dari beberapa pengertian di atas maka dapat disimpulkan bahwa dengan mempelajari perilaku konsumen dapat dilihat pengaruhpengaruh apa saja yang dapat mempengaruhi seorang konsumen dalam mengambil keputusan untuk membeli dan juga membantu para manajer dalam mengambil keputusannya. Perilaku konsumen 
dapat digunakan sebagai upaya untuk memberikan penilaian terhadap segala bentuk upaya dari konsumen untuk mendapatkan produk atau jasa sesuai dengan harapan.

$$
\text { Menurut Sutisna (2003) }
$$

terdapat 2 alasan mengapa perilaku atau gaya hidup konsumen perlu dipelajari yaitu, memahami konsumen akan menuntun pemasar pada kebijakan pemasaran yang tepat dan efisien. Dan perkembangan perdagangan pada saat ini menunjukkan bahwa lebih banyak produk yang ditawarkan dari pada permintaan. Kelebihan penawaran ini menyebabkan banyak produk yang tidak terjual atau tidak dikonsumsi oleh konsumen.

Empat elemen utama analisis perilaku konsumen: Pertama, adalah Afeksi dan Kognisi. Afeksi dan kognisi mengacu pada dua tipe tanggapan internal psikologi yang dimiliki konsumen terhadap rangsangan lingkungan dan kejadian yang berlangsung kognisi mengarah pada proses mental dan struktur pengetahuan yang dilibatkan dalam tanggapan seseorang terhadap lingkungannya.

Kedua, adalah Perilaku. Perilaku mengacu pada tindakan nyata konsumen yang dapat diobservasi secara langsung. Sementara afeksi dan kognisi mengacu pada perasaan dan pikiran konsumen. Sedangkan perilaku berhubungan dengan apa yang sebenarnya dilakukan konsumen.

Ketiga, adalah Lingkungan. Lingkungan mengacu pada rangsangan fisik dan sosial yang kompleks di dunia eksternal konsumen. Bagian penting dari lingkungan adalah rangsangan fisik dan sosial yang diucapkan oleh pemasar untuk mengajak konsumen.
Keempat, adalah Strategi Pemasaran. Startegi pemasaran dalah bagian dari lingkungan suatu individu dari berbagai rangsangan fisik dan sosial.

Berdasarkan uraian di atas maka dapat dikatakan bahwa elemen terkait dengan perilaku konsumen dan kegiatan yang dilakukan konsumen dalam menentukan keputusan yang akan ditetapkan. Elemen tersebut secara langsung memberikan dukungan konsumen dalam melakukan pembelian produk yang akan dilakukan pada perilaku konsumen menjadikan keputusan yang akan ditetapkan oleh konsumen (Peter dan Olson, 2000).

Gaya Hidup secara luas didefinisikan sebagai cara hidup yang diidentifikasikan oleh bagaimana orang menghabiskan waktu mereka (aktivitas), apa yang mereka anggap penting dalam lingkungannya (ketertarikan), dan apa yang dipikirkan tentang diri mereka sendiri dan juga dunia disekitarnya (pendapat). Menurut Sutisna (2003) gaya hidup masyarakat akan berbeda dengan masyarakat yang lainnya, bahkan dari masa ke masa gaya hidup suatu individu dan kelompok masyarakat tertentu akan bergerak dinamis. Namun demikian, gaya hidup tidak cepat berubah, sehingga pada kurun waktu tertentu gaya hidup relatif permanen.

Menurut Kotler (2002) Gaya hidup adalah cara ekspresi yang bersifat dasar dan unik yang muncul dalam bidang usaha manusia. Sedangkan menurut Lamb, Hair dan Mc Daniel (2001) adalah suatu cara hidup (mode of living), merupakan cara orang untuk memutuskan bagimana ia akan menghidupi 
hidupnya. Dengan kata lain, mereka akan memilih produk dan jasa yang memenuhi kebutuhan dan kepentingan yang beragam, dan bukannya menyesuaikan diri dengan stereotipe- stereotipe tradisional.

Para peneliti yang menganut pendekatan gaya hidup cenderung mengklasifikasikan konsumen berdasarkan variabel-variabel AIO yaitu aktifitas, minat (interest) dan opini (pandangan-pandangan). Kasali (2007) mengatakan bahwa segmentasi gaya hidup mengukur aktifitas-aktifitas manusia dalam hal yaitu, Bagaimana mereka menghabiskan waktunya?, Minat mereka, apa yang dianggap penting disekitarnya?, Pandanganpandangan, baik terhadap diri sendiri maupun terhadap orang lain, dan Karakter-karakter dasar seperti tahap merka telah lalui dalam kehidupan (life cycle), penghasilan, pendidikan dan mereka tinggal.

Komponen AIO didefinisikan oleh Renold dan Dearden dalam Engel (1994:385) sebagai berikut: 1 . Activities (kegiatan) adalah tindakan nyata seperti menontonsuatu mesium, berbelanja di toko atau menceritakan kepada tetangga mengenai pelayan yang baru. Walaupun tindakan ini biasanya dapat diamati, alasan untuk tindakan tersebut jarang dapat diukur secara langsung. 2. Interest (minat) akan semacam objek, peristiwa, atau topik adalah tingkat kegairahan yang menyertai perhatian khusus maupun terus menerus kepadanya. 3. Opinien (opini) adalah "jawaban" lisan atau tertulis yang orang berikan sebagai respon terhadap situasi stimulus dimana semacam "pertanyaan" diajukan. Opini digunakan untuk mendiskripsikan penafsiran, harapan, dan evaluasi seperti kepercayaan mengenai maksud orang lain, antisipasi sehubungan dengan peristiwa masa yang akan datang, dan penimbangan konsekuensi yang memberi ganjaran atau hukuman dari jalannya tindakan alternatif.

Gaya hidup yang berkembang pada masyarakat merefleksikan nilainilai yang dianut oleh masyarakat itu sendiri. Gaya hidup ditunjukkan oleh perilaku tertentu sekelompok orang atau masyarakat yang menganut nilai-nilai dan tata hidup yang hampir sama. Untuk memahami bagimana gaya hidup sekelompok masyarakat diperlukan program atau instrumen untuk mengukur gaya hidup yang berkembang. Menurut Sutisna (2003) untuk mengukur gaya hidup ditinjau dari aspek kultural, program ini disebut sebagai VALS 1 (Value And Life Style 1) yang terdiri dari: 1. Outer directed, yaitu merupakan gaya hidup konsumen yang jika dalam membeli suatu produk harus sesuai dengan nilai-nilai dan norma-norma tradisional yang telah terbentuk. Motivasi pembelian dipengaruhi oleh bagiamana pandangan dan pikiran orang lain atas pembelian itu. 2. Inner directed, kelompok konsumen yang membeli produk untuk memenuhi keinginan dari dalam dirinya untuk untuk memiliki sesuatu, dan tidak terlalu memikirkan norma-norma budaya yang berkembang. 3. Need driven, merupakan kelompok konsumen yang membeli sesuatu didasarkan atas kebutuhan dan bukan keinginan berbagai pilihan yang tersedia.

Perbaikan dilakukan untuk program VALS 1 dengan VALS 2 yang mengidentifikasikan beberapa kelompok konsumen yaitu sebagai berikut: 1. Actualizer, mempunyai 
pendapatan yang paling tinggi dan harga diri yang tinggi. Mereka mempunyai rentang minat yang luas pada berbagai bidang dan terbuka pada perubahan. Merka membeli produk untuk mencapai yang terbaik dalam hidup. 2. Fulfilleds, berpendapatan tinggi, dewasa, bertanggung jawab, mempunyai pendidikan tinggi dalam bidang profesional. Mereka memusatkan kegiatan senggang di rumah, tetapi terbuka pada gagasan baru dan perubahan. Mereka menghargai pendidikan dan travel, dan juga mempunyai kesadaran pada kesehatan. 3. Believers, agak kurang kaya, merka lebih tradisional daripada fulfilleds. Merka hidup terpusat pada keluarga, pergi ke masjid, gereja, kelompok dan negara. Mereka menghargai peraturan. 4. Striver, Minat sempit, mudah bosan, agak terkucil, ingin diakui oleh kelompok, tak peduli kesehatan dan tak peduli politik. 5. Struggler, minat terbatas, kegiatan terbatas, cari rasa aman, kesehatan bermasalah, konservatif dan tradisional, memegang agama. 6 . Experiencer, senang yang baru, aneh dan beresiko, senang olah raga, sosialisasi udara luar, peduli tentang citra, tidak sama dengan konformis, kagum kekayaan, kekuasaan, ketenaran, tidak peduli politik. 7 . Maker, menikmati alam, kegiatan fisik, waktu luang dengan kalangan dan teman dekat menghindari orang, mencemooh politisi, orang asing dan konglomerat.

Kerangka pikir merupakan alur penelitian yang akan digunakan, dimana dalam penelitian ini digunakan untuk mengetahui analisis gaya hidup pengguna Smartphone di Kota Malang. Adapun kerangka pikir dalam penelitian ini dapat dilihat pada gambar 1 .

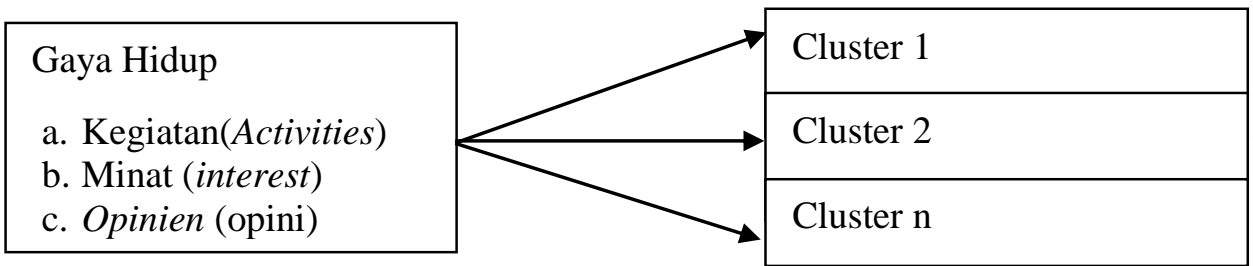

Gambar 1. Kerangka Berpikir

Kerangka pikir dapat digunakan untuk mempermudah alur pemikiran yang akan dilakukan dalam pembuatan skripsi. Berdasarkan gambar kerangka pikir di atas maka akan dilakukan analisis gaya hidup pengguna Smartphone di Kota Malang, yang meliputi kegiatan(activities) yaitu mengenai bekerja, hobi dan belanja. Variabel minat (interest) yaitu meliputi keluarga, pekerjaan dan media. Adapun untuk variabel opinien (opini) yaitu meliputi diri mereka sendiri, ekonomi, pendidikan, produk dan budaya (Renold dan Dearden dalam Engel, 1994).

\section{METODE PENELITIAN}

Lokasi penelitian di counter smartphone yang terdapat di Kecamatan Lowokwaru Kota Malang dengan obyek penelitian yaitu remaja yang menggunakan smartphone. Jenis penelitian yang lakukan ini adalah penelitian survey. Dalam penelitian ini data yang dipergunakan adalah data primer. Adapun yang 
menjadi populasi dalam penelitian ini adalah konsumen yang pengguna Smartphone di Kota Malang dengan karakteristik yaitu responden yang memiliki usia yang masuk dalam kategori remaja, menurut WHO (badan PBB untuk kesehatan dunia) batasan usia remaja adalah 13 sampai 24 tahun, dimana dalam penelitian ini ditekankan pada remaja awal yang berusia 13 sampai 15 tahun. Pemilihan teknik sampling dengan pertimbangan bahwa sampel yang digunakan dapat secara tepat mewakili populasi yang ada. Adapun ciri khusus tersebut yaitu remaja pengguna Smartphone di Kota Malang yang berusia 13 sampai 15 tahun.

Dalam penelitian ini teknik pengumpulan data primer yang dipergunakan adalah: kuesioner (angket), Alat analisis data yang digunakan untuk mengetahui gaya hidup remaja pengguna Smartphone di Kota Malangyaitu menggunakan cluster analysis. Analisis cluster adalah suatu prosedur yang pada prinsipnya digunakan untuk mereduksi data, yaitu proses meringkas sejumlah variabel menjadi lebih sedikit, cluster biasanya digunakan untuk melakukan segmentasi sejumlah responden (konsumen) berdasarkan ciri-ciri sejumlah atribut yang ada. suatu obyek dijabarkan dengan data multidimensi dan teknik pengelompokkan kecil yang dipilih untuk menyortir obyek tersebut ke dalam sejumlah kelompok yang telah ditentukan

\section{HASIL PENELITIAN DAN PEMBAHASAN}

Berdasarkan dari hasil analisis cluster yang telah dilakukan maka dapat diperoleh hasil untuk masingmasing cluster (kelompok) sehingga dapat digunakan untuk melakukangaya hidup remaja pengguna smartphone di Kota Malang. Hasil analisis cluster dapat diketahui bahwa jumlah anggota kelompok pada masing-masing cluster menunjukkan komposisi yang terdapat pada masing-masing cluster. Jumlah masing-masing cluster secara lengkap dapat dilihat pada tabel 2.

Tabel 2. Jumlah Masing-Masing Cluster

\begin{tabular}{ll}
\hline Cluster & Jumlah \\
\hline I & 54 \\
II & 18 \\
III & 28 \\
Total & 100 \\
\hline
\end{tabular}

Sumber: Data Primer Diolah

Berdasarkan Tabel 2 maka dapat diketahui jumlah masing-masing anggota kelompok atau cluster, dimana pada cluster 1 memiliki jumlah anggota yaitu sebanyak 54responden atau 54\% dan sebanyak 18 responden atau $18 \%$ pada cluster 2 dan sebanyak 28 responden atau $28 \%$ merupakan anggota kelompok dari cluster 3 .

Adapun hasil analisis cluster (karakteristik) secara lengkap dapat disajikan pada Tabel 3 .

Tabel 3. Hasil Analisis Cluster

\begin{tabular}{llll}
\hline Item & \multicolumn{3}{l}{ Cluster } \\
& 1 & 2 & 3 \\
\hline $\mathrm{X}_{1.1}$ & 4,06 & 3,56 & 3,43 \\
$\mathrm{X}_{1.2}$ & 4,02 & 3,33 & 3,79 \\
$\mathrm{X}_{1.3}$ & 4,02 & 3,22 & 3,89 \\
$\mathrm{X}_{2.1}$ & 4,15 & 3,39 & 3,46 \\
$\mathrm{X}_{2.2}$ & 4,13 & 3,17 & 3,36 \\
$\mathrm{X}_{2.3}$ & 4,02 & 3,39 & 3,75 \\
$\mathrm{X}_{3.1}$ & 4,06 & 3,67 & 3,86 \\
$\mathrm{X}_{3.2}$ & 3,69 & 3,06 & 4,00 \\
$\mathrm{X}_{3.3}$ & 3,85 & 3,61 & 3,68 \\
\hline
\end{tabular}

Sumber: Data Primer Diolah

Berdasarkan hasil final cluster pada tabel 3 maka dapat diketahui 
bahwa telah terbentuk tiga cluster, di mana masing-masing memiliki karakteristik yang berbeda yang dapat mencerminkan hasilgaya hidup remaja pengguna smartphone di Kota Malang. Ketiga cluster tersebut merupakan bentuk dari gaya hidup remaja pengguna smartphone

di Kota Malang sehingga dapat digunakan atau memberikan gambaran tentang sejauh mana cluster tersebut dapat menentukan gaya hidup remaja pengguna smartphone. Berdasarkan hasil analisis final cluster tersebut maka dapat diuraikan sebagai berikut:

Tabel 4. Hasil Karakteristik Cluster

\begin{tabular}{|c|c|c|}
\hline No. & Cluster & Karakteristik \\
\hline 1. & $\begin{array}{ll}\text { Cluster } & I \\
\text { (Pengaruh } & \\
\text { Lingkungan) }\end{array}$ & $\begin{array}{l}\text { - Pekerjaan atau aktivitas rutin yang dilakukan }\left(\mathrm{X}_{1.1}\right) \\
\text { - Perkembangan media informasi }\left(\mathrm{X}_{1.2}\right) \\
\text { - Kegiatan yang dilakukan oleh seseorang sebagai } \\
\text { sumber pendapatan }\left(\mathrm{X}_{1.3}\right) \\
\text { - Lingkungan yang paling dekat dengan seseorang }\left(\mathrm{X}_{2.1}\right) \\
\text { - Selalu memiliki keinginan untuk melakukan } \\
\text { pembelian produk terbaru }\left(\mathrm{X}_{2.2}\right) \\
\text { - Lebih mengutamakan pembelian barang seusai } \\
\text { - keinginan daripada kebutuhan }\left(\mathrm{X}_{2.3}\right) \\
\text { - Menunjang penampilan }\left(\mathrm{X}_{3.1}\right) \\
\text { - Menambah relasi/ rekan }\left(\mathrm{X}_{3.3}\right)\end{array}$ \\
\hline 2. & $\begin{array}{l}\text { Cluster III } \\
\text { (Perkembangan } \\
\text { Teknologi) }\end{array}$ & - Mengikuti perkembangan teknologi $\left(\mathrm{X}_{3.2}\right)$ \\
\hline
\end{tabular}

Sumber: Data Primer Diolah

Berdasarkan hasil analisis dapat diketahui bahwa terdapat dua kelompok atau cluster yang terbentuk dan masing-masing dapat diuraikan sebagai berikut: Pada Cluster I (Pengaruh Lingkungan), kelompok terbentuk karena adanya adanya keinginan responden untuk mendukung pekerjaan ruitn yang dilakukan, pekerjaan rutin yang banyak dilakukan oleh remaja dimana aktivitas yang dilakukan misalnya melakukan penjualan pulsa dan menjalankan binis online. Aktivitas yang dilakukan responden tersebut sangat terbantu dengan adanya keberadaan smartphone. Pada cluster ini juga mempertimbangkan adanya perkembangan media informasi, dimana perkembangan teknologi yang selalu berkembang menjadikan responden selalu berupaya untuk mendapatkan smartphone yang benar-benar dapat mendukung perkembangan teknologi yang terjadi.

Kegiatan yang dilakukan oleh seseorang sebagai sumber pendapatan juga menjadi pertimbangan responden dan menjadi gaya hidup pengguna smartphone. Kenyataan ini dapat menunjukkan bahwa selain sebagai media komunikasi smartphone juga memiliki peran penting untuk meningkatkan jumlah relasi sehingga memiliki dukungan dalam upaya peningkatan pendapatan yang dimiliki responden. Pada lingkungan yang paling dekat dengan seseorangjuga menjadi dorongan responden untuk melakukan pembelian smartphone untuk mendukung gaya hidup remaja. Lingkungan yang paling dekat banyak memberikan masukan atau informasi 
yang dapat dipercaya terkait dengan keberadaan smartphone.

Responden juga selalu memiliki keinginan untuk melakukan pembelian produk terbarudengan harapan dapat mengikuti perubahan teknologi yang terjadi sehingga segala bentuk keunggulan produk dapat dirasakan oleh responden. Pada cluster ini juga lebih mengutamakan pembelian barang seusai keinginan daripada kebutuhan, dimana keinginan yang dimiliki oleh responden untuk mengikuti perubahan teknologi menjadikan responden selalu berupaya untuk mendapatkan smartphone sesuai dengan keinginan dan harapan responden. Menunjang penampilan menjadi salah satu pembentuk gaya hidup responden sehingga dengan penampilan yang sesuai dengan keinginan atau harapannya. Adapun karakteristik terakhir yaitu mengenai menambah relasi/ rekan dengan tujuan membentuk relasi yang dapat mendukung aktivitas yang dilakukan.

Cluster III (Perkembangan Teknologi) ini memiliki karakteristik yaitu adanya keinginan responden untuk mengikuti perkembangan teknologi, dimana perkembangan teknologi yang terjadi akan memberikan dukungan atau peluang untuk mengembangan potensi yang dimiliki terkait dengan aktivitas yang dilakukan. Perkembangan teknologi secara langsung juga memberikan dukungan dalam mendapatkan informasi yang penting sehingga responden akan dapat menggunakan atau memanfaatkan informasi tersebut dalam mendukung gaya hidupnya.

\section{SIMPULAN}

Dari hasil penelitian dan pembahasan dengan menggunakan analisis cluster yang telah dilakukan maka dapat ditarik kesimpulangaya hidup remaja pengguna Smartphone di Kota Malang dapat terbagi menjadi tiga kelompok yang masing-masing dapat diuraikan bahwa pada cluster I memiliki karakteristik yaitu adanya keinginan responden untuk mendukung pekerjaan ruitn yang dilakukan, pekerjaan atau aktivitas rutin yang dilakukan, perkembangan media informasi, kegiatan yang dilakukan oleh seseorang sebagai sumber pendapatan, lingkungan yang paling dekat dengan seseorang, Selalu memiliki keinginan untuk melakukan pembelian produk terbaru, lebih mengutamakan pembelian barang seusai keinginan daripada kebutuhan, menunjang penampilan dan menambah relasi/ rekan. Cluster III ini memiliki karakteristik yaitu adanya keinginan responden untuk mengikuti perkembangan teknologi, dimana hal ini menjadikan responden selalu berupaya untuk mendapatkan informasi yang lengkap dengan memanfaatkan perkembangan teknologi.

\section{DAFTAR PUSTAKA}

Anugrah. 2011. Pengaruh Sikap Terhadap Produk dan Gaya Hidup Brand Minded Terhadap Keputusan Membeli Smartphone Blackberry Pada Siswa SMA. Al-Azhar: Bumi Serpong Damai

Basu Swasta, dan Hani Handoko. 2000. Manajemen Pemasaran Analisa Perilaku Konsumen, Yogyakarta: BPFE.

Charles W. Lamb Jr, Joseph F. Hair Jr, Carl Mc. Daniel. 2001. Pemasaran, Edisi Pertama, 
Jilid Kedua. Jakarta: Salemba Empat.

Engel, F. James; Roger D. Blackwell; Paul W. Miniard. 2004. Perilaku. Konsumen. Jakarta: Binarupa Aksara

Hanim. 2011. Komponen yang mempengaruhi keputusan membeli handphone Blakberry dan gaya hidup konsumen. Skripsi Universitas Brawijaya Malang

Henry, Assael. 2001. Consumer Behavior and Marketing Action. USA: Thomson \& Learning.

James F. Engel, Roger D. Blackwell and Paul W. Miniard. 1994. Perilaku Konsumen. Jakarta: Binarupa Angkasa.

John C. Mower, Michael Minor. 2002. Perilaku Konsumen, Edisi Kelima. Jakarta: Erlangga.

Kotler, Philip. 2002. Manajemen Pemasaran. Jakarta: PT. Prenhallindo. 2007. Manajemen

Pemasaran: Perencanaan, Implementasi dan

Pengendalian. Jakarta:

Prehallindo.

Kasali, Rhenald. 2007. Membidik Pasar Indonesia Segmentasi Targeting Positioning. Jakarta: PT Gramedia Pustaka Utama.

Mayasari. 2012. Analisis Perilaku Konsumen Pembelian Ponsel Cerdas Antara Kebutuhan Dan Gaya Hidup Konsumen Di Kota Padang. Skripsi
Universitas Brawijaya Malang.

Mowen, John, C dan Michael Minor. 2002. Perilaku Konsumen. Jilid Kedua. Jakarta: Erlangga

Naresh, K Maholtra. 2005. Riset Pemasaran, Pendekatan Terapan, Jilid Pertama. Jakarta: PT. Indeks Kelompok Gramedia.

Peter, Paul J, dan Olson, Jerry C. 2000. Consumer Behavior: Perilaku Konsumen Dan Strategi Pemasaran, Edisi Keempat. Jakarta: Erlangga.

Purba. 2013. Pengaruh gaya hidup terhadap proses keputusan pembelian smarthphone berbasis android. Skripsi Universitas Brawijaya Malang.

Sutisna. 2003. Perilaku Konsumen dan Komunikasi Pemasaran. Bandung: PT Remaja Rosdakarya.

Singarimbun, Masri dan Effendi. 1995. Metode Penelitian Survai, Edisi Revisi. Jakarta: LP3S.

Singgih Santoso \& Fandy Tjiptono. 2000. Riset Pemasaran Konsep dan Aplikasi dengan SPSS. Jakarta: PT. Gramedia.

Suharsimi, Arikunto. 1998. Prosedur Penelitian Suatu Pendekatan Praktek, Edisi Revisi Keempat. Jakarta: Rineka Cipta.

Widayat dan Amirullah. 2002. Riset Bisnis, Edisi 1. Malang: CV. Cahaya Press. 